\title{
Norman Bowery's Discoveries about Extrasynaptic and Asynaptic GABA Systems and their Significance ${ }^{1}$
}

\author{
David A. Brown
}

Department of Neuroscience, Physiology \& Pharmacology, University College London, London, WC1E 6BT, UK.

\begin{abstract}
Before finding the GABA-B receptor, Norman Bowery completed a series of studies on an extrasynaptic or asynaptic "GABA system" in the rat superior cervical sympathetic ganglion. First, he discovered an uptake system for GABA in neuroglial cells in the ganglia and in peripheral nerves, with a different substrate specificity than that in neurons. Second, he showed that accumulated GABA in sympathetic glial cells was metabolized to succinate by a transaminase enzyme. Third, he provided detailed structure-activity information about compounds activating an extrasynaptic GABA-A receptor on neurons in the rat sympathetic ganglion. Fourth, he showed that some amino acid substrates for the neuroglial transporter could indirectly stimulate neurons by releasing GABA from adjacent glial cells, and that GABA could also be released from neuroglial cells by membrane depolarization. In this review, these discoveries are briefly described and updated and some of their implications assessed.

[143 words]
\end{abstract}

\section{Highlights}

- $\quad$ GABA is taken up by a $\mathrm{Na}^{+}$-dependent transporter in peripheral neuroglial cells.

- $\mathrm{GABA}$ is metabolized to succinate by neuroglial cells

- Peripheral neurons devoid of GABAergic input can be depolarized by GABA via asynaptic GABA-A receptors.

- Some amino acids can activate neuronal GABA receptors by releasing GABA from adjacent glial cells.

[50 words]

Key words: sympathetic ganglion; sensory ganglia; neuroglial cells; GABA uptake; GABA release; GABA-A receptor; GABA depolarization

5394 words including title, abstract, highlights, key words, references and figure legends

\footnotetext{
${ }^{1}$ Material in italics summarizes subsequent relevant work and its implications
} 


\section{Introduction}

Norman is rightly renowned for his discovery of the GABA-B receptor. However, in the years BGB (Before GABA-B) he completed an almost-equally innovative series of studies on the components of an extra-synaptic (indeed, substantially asynaptic) GABA "system" in the rat superior cervical sympathetic ganglion, with overspill into other parts of the peripheral nervous system. This work started when he joined us in 1970 at Barts Hospital Medical School as an MRC postgraduate research student from CIBA-Geigy in Horsham UK.

Earlier that year I had spent a semester at the University of Chicago where Lloyd Roth and Walter Stumpf had developed a high-resolution autoradiographic method for immobilizing and locating soluble radiolabelled compounds (Stumpf \& Roth, 1966) so I thought to use this to locate neurons that took up radiolabelled GABA as being potentially-GABAergic neurons ${ }^{2}$. However, before embarking on time-consuming autoradiography, I thought first to check how the uptake of ${ }^{3} \mathrm{H}-\mathrm{GABA}$ into brain slices (which presumably contained GABAergic neurons) compared with that into a tissue like the sympathetic ganglion (which presumably did not). To my surprise, the isolated ganglion took up as much ${ }^{3} \mathrm{H}-\mathrm{GABA}$ as the brain slice as measured by the tissue:medium concentration ratio, though it took longer to do so.

Hence, when Norman joined us I suggested he might start by having a closer look at GABA uptake in sympathetic ganglia and other non-GABAergic tissues. As those who know him will attest, Norman was never one to let the grass grow under his feet, and no sooner said than done. In a remarkably short time ${ }^{3}$ he completed and published an account of the uptake system (which turned out to be neuroglial in origin). He then went on to complete a survey of the GABA receptors on the sympathetic neurons, and further showed that GABA could be metabolized by the GABA

\footnotetext{
${ }^{2}$ Tomas Hokfelt had the same idea and published a paper on the autoradiographic localization of ${ }^{3} \mathrm{H}-\mathrm{GABA}$ in cerebellar slices later that same year (Hokfelt \& Ljungdahl, 1970).
}

${ }^{3}$ E.g., a presentation at the Physiological Society within a year (Bowery \& Brown, 1971) 
transaminase system in the ganglion. Thus, by the end of 1974 he had published 4 papers on the ganglionic GABA system, completed a very substantial thesis describing a new chapter in the GABA-A story and been awarded a PhD. He stayed with us for couple more years doing some follow-up experiments on the glial transporter (showing, for example, that the glial cells acted as a source of GABA for activating neighbouring neurons), before departing to horizons new.

Throughout his stay in our lab, in whatever facet of GABA he was studying (transport, receptors, metabolism), Norman would eventually test a drug that he had been working on at CIBA called Lioresal (baclofen; $\beta$-chlorophenylGABA), a centrally-acting muscle relaxant thought to be a GABAmimetic - but every time it had no clear effect. However, new pastures obviously refreshed since, no sooner had he left us to run his own lab $^{4}$ than he discovered a new type of GABA receptor

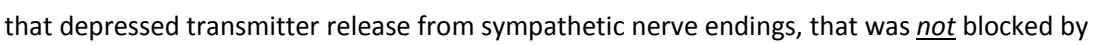
bicuculline (Bowery \& Hudson, 1979), and - at long last - was activated by baclofen (Bowery et al., 1979a). There must be a moral here somewhere.

\section{Asynaptic GABA transport.}

In his initial experiments (Bowery \& Brown, 1972a), Norman identified a sodium-dependent uptake mechanism for ${ }^{3} \mathrm{H}-\mathrm{GABA}$ in rat sympathetic ganglia that, in the presence of a transaminase inhibitor, was capable of generating an overall intra:extracellular concentration ratio of around 100 at an external GABA concentration of $0.5 \mu \mathrm{M}$. Uptake was saturable with an apparent $\mathrm{Km}$ of $0.4 \mu \mathrm{M}$. He noted that this process was similar to that previously described for isolated brain tissue (e.g., Iversen \& Neal, 1968) except that (a) ganglionic uptake was much slower (partly due to connective tissue diffusional barriers) and (b) there were differences in substrate specificity in that ganglionic uptake was shared with, and more readily inhibited by, $\beta$-alanine, and less well shared with or inhibited by 2,4-diaminobutyric acid (DABA), than that previously described for brain tissue (Iversen \& Johnston, 1971). He further noted a comparable concentrative uptake into other peripheral neural tissue such as preganglionic sympathetic nerve trunks, vagus nerves and (to a lesser extent) sciatic nerves, but not into skeletal, cardiac or smooth muscle, nor into adrenal glands. Finally, he showed that accumulated ${ }^{3} \mathrm{H}-\mathrm{GABA}$ could be released from the isolated ganglion by raising extracellular [ $\mathrm{K}^{+}$] but not by selectively depolarizing the neurons with carbachol. This, coupled with the lack of effect of degenerative section of the preganglionic sympathetic trunk on ${ }^{3} \mathrm{H}-\mathrm{GABA}$ uptake (thus eliminating uptake into preganglionic fibres and terminals), was taken to imply that some at least of the ${ }^{3} \mathrm{H}$ GABA was taken up into glial cells.

\footnotetext{
${ }^{4}$ at St.Thomas's Hospital Pharmacology Department
} 
This inference (of glial uptake) was subsequently confirmed by some autoradiograph experiments on sympathetic and nodose (visceral sensory) ganglia (Young et al., 1974) that were published in conjunction with work by Fred Schon and John Kelly in Leslie Iversen's lab ${ }^{5}$. These showed an almost exclusively extraneuronal accumulation of ${ }^{3} \mathrm{H}-\mathrm{GABA}$ in the Schwann cells surrounding unmyelinated axons (which presumably accounts for its uptake into vagus nerves: Bowery \& Brown, 1972a) and into satellite cells surrounding the neurons (also in somatosensory ganglia: see Schon \& Kelly, 1974). There was virtually no uptake into neurons (Fig.1)

[Fig.1 near here]

It soon became clear that other neuroglial cells, including some in the brain, possessed a similar transport system for GABA (Iversen and Kelly, 1975). In view of this, Norman and his colleagues undertook a more detailed study of the glial transport system in the sympathetic ganglion (Bowery et al., 1979a). They found that the uptake could be described by a pump-and-leak system with a saturable influx ( $\mathrm{K}_{\mathrm{T}} 6.8 \mu \mathrm{M}$; initial velocity $7 \mu \mathrm{mole}^{-1}$ (cell fluid) $\mathrm{min}^{-1}$ ) and an efflux rate constant of $7 \times 10^{-4} \mathrm{~min}^{-1}$. This yielded a steady-state set point (where uptake and efflux were equal) of $0.9 \mu \mathrm{M}$ external [GABA], under conditions in which metabolism of GABA by the satellite cells was blocked (see further below) and intra-glial [GABA] was $1.6 \mathrm{mM}$. This implies that the transporter operated in net uptake mode at the normal rat plasma GABA concentration of $\sim 10 \mu \mathrm{M}$. Since the satellite cells containing the transporter closely envelope the sympathetic neurons, satellite cell uptake might help to keep the concentration of GABA in plasma exudates around the neurons below the threshold $(1 \mu \mathrm{M})$ required to activate the GABA receptors on those neurons (Bowery \& Brown, 1974-see further below).

In parallel experiments, Norman and his colleagues also continued work on the GABA efflux process in the satellite cells. First, they made the important discovery that substrates for the carrier that alone were devoid of actions on GABA receptors, such as $\beta$-alanine and $\beta$-aminobutyric acid (BABA), could act as indirect GABAmimetics by releasing enough GABA from the glial cells to activate neighbouring neurons (Bowery et al., 1976a6; see Fig.2).

[Fig. 2 near here]

In further experiments on the release of GABA from the glial cells by "depolarizing stimuli", Norman found that neither $\mathrm{K}^{+}$-evoked release nor that induced by an electric current was sensitive

\footnotetext{
${ }^{5}$ At that time undertaking comparable GABA uptake experiments on somatic sensory ganglia (Schon \& Kelly, 1974).

${ }^{6}$ Notwithstanding the list of authors, this really was Norman-inspired work.
} 
to external $\left[\mathrm{Ca}^{2+}\right]$ or to tetrodotoxin, and hence was not vesicular in origin or dependent on action potential generation, but most probably resulted from local membrane depolarization (Bowery et al., 1979b).

Norman's pioneering work on this glial transport system predated the purification and cloning of the GABA transporters but anticipated some of the main findings. The first of these, the neuronal transporter GAT-1, was cloned by Guastella et al in 1990. It transports $2 \mathrm{Na}^{+}$ions for each GABA molecule and hence is electrogenic, i.e., generates an inward current accompanying GABA uptake (Mager et al., 1993). This would explain why raising external $K^{+}$stimulated efflux (Bowery et al., 1979b): the depolarization would reduce the uptake rate and favour a GABA counter-efflux. Four GABA transporters have been isolated, GAT 1-4. From a substrate specificity viewpoint (high Balanine sensitivity, low 2,4-diaminobutyric acid sensitivity) the peripheral glial transporter aligns best with GAT-3 (Borden, 1996). GAT-3 is expressed in central astrocytes (Park et al., 2009), particularly in extrasynaptic processes (Melone et al., 2015) but GAT-1 drives GABA uptake in Bergmann glia (Barakat \& Bordey, 2002) and oligodendrocytes (Fattorini et al., 2017). Substrate-induced counterefflux of GABA may either be through accelerated exchange or (as suggested by Bowery et al.,1976a) inhibited re-uptake of a GABA efflux "leak". One source of the latter might be through Best-1 bestrophin anion channels (Lee et al (2010); this is worth testing.

A glia-derived component of indirect GABAmimetic action by carrier substrates like that described by Norman in 1976 (Bowery et al., 1976a) has subsequently been deduced in some central loci (e.g., Brown et al, 1980; Wall \& Usowicz, 1997; Gaspari et al., 1998; Barakat \& Bordey, 2002). The glial transporter may be particularly significant for the regulation of tonic neuronal GABA currents (Semyanov et al., 2003; Rossi et al., 2003; Kinney, 2005; Park et al., 2009) or GABA-B receptor-mediated effects (Unichenko et al., 2015), which are sensitive to lower concentrations of GABA than most GABA-A receptors.

\section{Asynaptic GABA receptors.}

If there are carriers for GABA in sympathetic ganglia, why not receptors? W.C.("Chet") de Groat (1970) was the first to indicate this possibility. He injected GABA into the arterial supply to the superior cervical ganglia of anaesthetized cats and observed a surface depolarization of the ganglion accompanied by an inhibition of ganglionic transmission, which was blocked by picrotoxin. Norman chased this up using the isolated rat superior cervical ganglion (Bowery \& Brown, 1974). He 
completed a comprehensive and quantitative survey of agonist potencies which accorded with their known activity on central neurons as derived from studies using iontophoresis (brain slice preparations then being still in an embryonic state). Interestingly, the ganglion cells appeared not to express receptors for glycine or glutamate. Ever the practical pharmacologist, Norman suggested that this (and other factors) made the ganglion preparation ideal for quantitative assays of drugs interacting with GABA receptors, and made subsequent use of this on several occasions. For example, he used this preparation to answer the thorny question whether $y$-aminobutyrylcholine (GABACh) acted like GABA or acetylcholine (Bowery \& Brown, 1972b; see Fig.3)). The answer was strongly on the side of GABA: GABACh showed half the depolarizing potency of GABA itself and was antagonized by bicuculline but not by a combination of hyoscine and hexamethonium that suppressed the effect of carbachol. This GABAmimetic effect was likely due mainly to hydrolysis of GABACh to GABA by ganglionic cholinesterase because the potency of GABACh on the GABA receptors was reduced about 50 times when the cholinesterase was inhibited by physostigmine or neostigmine. ${ }^{7}$ Other examples where Norman's ganglion preparation provided a useful assay for drug - GABA receptor interaction include: the demonstration that the convulsant tetramethylenedisulphotetramine (TETS) acted as a reversible non-competitive GABA antagonist (Bowery et al, 1975); quantitation (with G.P.Jones, a chemical colleague) of GABA receptor agonist activity of several conformationally-restricted GABA analogues (Bowery \& Jones., 1976); the discovery that some bicyclic phosphorus esters, previously thought to be anticholinesterase agents, acted as GABA antagonists (Bowery et al., 1976b); and the discovery (with Andy Dray) that pentobarbitone reversed the action of GABA antagonists such as bicuculline (Bowery \& Dray, $1976)^{8}$.

\section{[Fig. 3 near here]}

In his original paper (Bowery \& Brown, 1974), Norman also noted that application of GABA during an ongoing carbachol-induced depolarization generated a hyperpolarizing response, suggesting a more negative reversal potential (and hence different ionic conductance change) than that for the nicotinic response. Companion microelectrode studies by Adams \& Brown $(1973,1975)$ yielded a reversal potential of around $-42 \mathrm{mV}$ with microelectrodes filled with potassium acetate or citrate, and provided evidence that the response to GABA was mediated by an increased chloride conductance, as in central neurons. The depolarization was therefore attributed to a high intracellular chloride concentration (around $24 \mathrm{mM}$ ) maintained by a then-unknown inward chloride pump. Comparable chloride-mediated depolarizing responses to GABA have also been observed in

${ }^{7}$ An instructive example of Norman's insightful pharmacological detective work

${ }^{8}$ Examples of Norman's flair for setting up productive experimental collaborations 
peripheral sensory neurons (De Groat, 1972; Nishi et al., 1974; Deschennes et al., 1976; Gallagher et al., 1978), and even in unmyelinated peripheral nerve fibres in cervical sympathetic and vagus nerve trunks (Brown \& Marsh, 1978).

In this respect, these peripheral neurons resemble early developmental mammalian central neurons, in which a high intracellular chloride concentration is maintained by expression of the NKCC1 Na $/ \mathrm{K}^{+} / \mathrm{Cl}^{-}$co-transporter (Payne et aL, 2003). Later developmental expression of the KCC2 or $K C C 3 \mathrm{~K}^{+} / \mathrm{Cl}^{-}$co-transorter then enables extrusion of $\mathrm{Cl}^{-}$to reduce $E_{C l}$ below $E_{m}$ in the adult central neurons so that GABA produces its normal hyperpolarization (Ben-Ari et al., 2007), In peripheral neurons this developmental switch does not occur, presumably because KCC2 expression is too low (Kanaka et al., 2001) to overcome a persistent high NKCC1 expression (Chabwine et al., 2009). In developing central neurons, the activity of endogenous (synaptically-released) GABA itself seems to act as a trigger for developmental KCC2 expression and subsequent chloride extrusion (Ganguly et al., 2001). Presumably, most peripheral neurons see too little GABA for this to occur.

\section{Physiological functions of peripheral neural GABA systems}

As mentioned, the rationale for Norman's original experiments on sympathetic ganglia was that the synapses therein were not GABAergic. Thus, in a comprehensive study of amino acid metabolism in isolated rat superior cervical ganglia, Nagata et al (1966) were unable to detect free GABA nor any radiolabelled GABA uptake or mechanisms for its synthesis by glutamic acid decarboxylase or metabolism by GABA - $\alpha$-keto acid transaminase. Likewise, McBride \& Klingman (1972) were unable to detect any GABA in the ganglion by gas-liquid chromatography, and commented that this "appears to preclude any functional role for GABA in rat-sympathetic ganglia." Norman's discovery of the GABA uptake system (Bowery \& Brown, 1972a) obviously contrasted with Nagata et al's (1966) observation. Further, during those experiments, Norman noted that uptake was faster and greater in the presence of amino-oxyacetic acid, a GABA - $\alpha$-keto acid transaminase inhibitor, In further experiments with John Clark and colleagues in the Biochemistry Department at Barts (Walsh et al., 1974), Norman confirmed that GABA accumulated by the rat ganglion was metabolized to succinate by the GABA - $\alpha$-keto acid transaminase enzyme and then to citrate by succinic semialdehyde dehydrogenase - presumably by the satellite glial cells. This strengthens the view (Bowery et al., 1979a) that the glial uptake process is a protective mechanism against an effect of excessive plasma GABA levels on the enclosed sympathetic neurons and fibres. Conversely, and, in agreement with Nagata et al (1966), Walsh et al (1974) were unable to detect any glutamic acid decarboxylase activity, confirming that GABA was unlikely to have any neurotransmitter function in the ganglion. 
Subsequent work has suggested that we might have been unduly cautious and that GABA may have some transmitter-like functions in peripheral ganglia. Regarding the rat superior cervical ganglion (SCG) itself, Bertilsson et al (1976) positively identified low amounts of GABA (about 300 pmole/mg. protein, a fraction of that in brain) in rat SCG by mass fragmentometry. This was enhanced severalfold by inhibiting GABA transaminase and reduced by about $50 \%$ by chronic preganglionic nerve section, suggesting that it was not just sequestered from plasma but partly under neural control. Further, there have been several reports that a proportion of the afferent nerves in the ascending preganglionic trunk, and their varicosities within the ganglion, are immunoreactive for GABA or its synthesizing enzyme GAD67 (e.g., Wolff et al., 1986, 1989; Dobo et al., 1989; Ito et al., 2007; Elinos et al., 2016) [although none of the principal neurons stained for GAD67]. These afferent "gabaergic fibres" appear to derive from the ventral spinal cord and most or all co-stain for choline acetyltransferase so are also cholinergic. There is also some evidence that they may subserve a component of gabaergic synaptic inhibition since Daniel Eugène (1987) recorded a residual small depolarizing post-synaptic potential from rat SCG neurons following afferent stimulation when cholinergic transmission was blocked, which was suppressed by bicuculline. The functional significance of this is not yet clear. Notwithstanding, our initial supposition (Bowery \& Brown, 1972a) that GABA did not play a major transmitter role in the rat SCG seems justified if one inserts the word "major".

One would imagine that the same "non-transmitter"epithet would also apply to the action of GABA on neurons in sensory ganglia, especially since these ganglia are normally devoid of external synaptic connections. Thus, initially, the depolarization of sensory neuron somata was regarded simply as a "model" for effect of GABA on the primary afferent fibres in the spinal cord to produce primary afferent depolarization (Deschennes et al., 1976). However, more recent work has revealed an important role of GABA in sensory nociception. Thus, the expression of DRG GABA receptors is reduced in experimental nerve injury-induced peripheral neuropathy (Obata et al., 2003). Further, in this neuropathic pain model, local application of the GABA receptor agonist muscimol into the DRG transiently alleviated the hyperalgesia, whereas local injection of bicuculline or picrotoxin worsened the pain (Naik et al, 2008). The latter implies that the ganglion cells or their central processes must have been exposed to GABA, since comparable dye injections did not spread into the dorsal horn. Very recently, Du et al (2017) have provided evidence for a true, transmitter-like function of GABA within the sensory ganglia themselves. They showed that individual nociceptive sensory neuron somata in culture release GABA (detected with a GABA receptor membrane patch electrode) when challenged with the nociceptive stimulant capsaicin. They also found that some 8-9\% of sensory neurons also expressed mRNA for GAD67, GAD65 and VGAT (the vesicular GABA transporter), while 
nearly half the neurons expressed the neuronal GABA transporter GAT1. Additionally, the synaptic vesicle marker protein SV2 could be detected in many neurons by immunostaining. Thus, unlike sympathetic neurons, a substantial number of the sensory neurons in dorsal root ganglia possess the machinery for manufacturing, secreting and recapturing GABA. Then, in experimental tests of acute and chronic pain sensation, Du et al (2017) found that local application of GABA or muscimol reduced pain, that a GAT1 uptake inhibitor also reduced pain, but that bicuculline enhanced pain - the effects of bicuculline and the uptake inhibitor implying the local release of GABA. They conclude that, when nociceptive neurons within the primary sensory ganglia are activated, they release sufficient GABA locally to reduce the safety factor for nerve conduction through the sensory nerve bifurcation within the ganglia and so acts as an anti-nociceptive "gate".

\section{Conclusions.}

Norman's pioneering experiments on sympathetic ganglia led to several new concepts in GABA signalling, for example: glial cell uptake; glial cells as a source of GABA for indirect GABAmimetic drug action; and the fact that GABA can depolarize neurons as well as hyperpolarize them. However, perhaps his greatest bequest was the introduction of controlled and measurable "gutbath" style pharmacology of isolated neural tissues into the world of GABA signalling. This served him well for the next phase of his adventures with GABA, the discovery of the GABA-B receptor.

\section{Acknowledgements.}

Norman was initially funded through a UK Medical Research Council (MRC) postgraduate studentship and his research funded by a grant from the American Medical Association Education and Research Foundation. He was later funded through a research grant from the UK MRC to the author. 


\section{References}

Adams PR, Brown DA. (1973). Action of $\gamma$-aminobutyric acid (GABA) on rat sympathetic ganglion cells.y Br J Pharmacol. 47):639P-640P..PMID:4730853

Adams PR, Brown DA. (1975) Actions of gamma-aminobutyric acid on sympathetic ganglion cells. J Physiol. 250:85-120. PMID:1177140

Barakat L, Bordey A. (2002). GAT-1 and reversible GABA transport in Bergmann glia in slices. J Neurophysiol. 88:1407-1419.

Ben-Ari Y, Gaiarsa JL, Tyzio R, Khazipov R. (2007). GABA: a pioneer transmitter that excites immature neurons and generates primitive oscillations. Physiol Rev 87:1215-84.

Bertilsson L, Suria A, Costa E.(1976). p-aminobutyric acid in rat superior cervical anglion. Nature. 1976 260:540-541. PMID:1264214

Borden LA (1996) Gaba transporter heterogeneity: Pharmacology and cellular localization. Neurochem Int 29:335-356.

Bowery NG, Brown DA. (1971). Observations on ( $3 \mathrm{H}$ ) -aminobutyric acid accumulation and efflux in isolated sympathetic ganglia. J Physiol. 218 Suppl:32P-33P. PMID: 5130619

Bowery NG, Brown DA. (1972a), y-Aminobutyric acid uptake by sympathetic ganglia.Nat New Biol. 238:89-91. PMID: 4505419

Bowery NG, Brown DA. (1972b). p-Aminobutyrylcholine: actions on GABA and acetylcholine receptors. J Pharm Pharmacol.24:663-666.PMID:4403753

Bowery NG, Brown DA. (1974) Depolarizing actions of gamma-aminobutyric acid and related compounds on rat superior cervical ganglia in vitro. Br J Pharmacol. 50:205-218. PMID:4154116

Bowery NG, Brown DA, Collins JF. (1975). Tetramethylenedisulphotetramine: an inhibitor of gammaaminobutyric acid induced depolarization of the isolated superior cervical ganglion of the rat. $\mathrm{Br} J$ Pharmacol. 53:422-424.PMID:165847

Bowery NG, Brown DA, Collins GG, Galvan M, Marsh S, Yamini G. (1976a). Indirect effects of aminoacids on sympathetic ganglion cells mediated through the release of gamma-aminobutyric acid from glial cells. Br J Pharmacol. 57:73-91.PMID:1276543

Bowery NG, Brown DA, Marsh S. (1979b) $\psi$-Aminobutyric acid efflux from sympathetic glial cells: effect of 'depolarizing' agents. J Physiol. 293:75-101. PMID:501652

Bowery NG, Brown DA, White RD, Yamini G.(1979a). [3H]gamma-Aminobutyric acid uptake into neuroglial cells of rat superior cervical sympathetic ganglia. J Physiol. 293:51-74.PMID:501628 
Bowery NG, Collins JF, Hill RG. (1976b). Bicyclic phosphorus esters that are potent convulsants and GABA antagonists. Nature. 261:601-603. PMID: 934303

Bowery NG, Doble A, Hill DR, Hudson AL, Shaw JS, Turnbull MJ. (1979c).Baclofen: a selective agonist for a novel type of GABA receptor. Br J Pharmacol. 67:444P-445P. PMID: 227517

Bowery NG, Dray A.(1976) Barbiturate reversal of amino acid antagonism produced by convulsant agents. Nature. 264:276-278.PMID:187949

Bowery NG, Hudson AL. (1979) gamma-Aminobutyric acid reduces the evoked release of [3H]noradrenaline from sympathetic nerve terminals Br J Pharmacol. 66:108P. PMID:454903

Bowery NG, Jones GP (1976). A comparison of gamma-aminobutyric acid and the semi-rigid analogues 4-aminotetrolic acid, 4-aminocrotonic acid and imidazole-4-acetic acid on the isolated superior cervical ganglion of the rat. Br J Pharmacol. 56:323-330. PMID:1260178

Brown DA, Collins GG, Galvan M. (1980). Influence of cellular transport on the interaction of amino acids with gamma-aminobutyric acid (GABA)-receptors in the isolated olfactory cortex of the guineapig. Br J Pharmacol. 68:251-262. PMID:6244038

Brown DA, Marsh S. (1978). Axonal GABA receptors in mammalian peripheral nerve trunks. Brain Res 156: $187-191$

Chabwine JN, Talavera K, Verbert L, Eggermont J, Vanderwinden JM, De Smedt H, Van Den Bosch L, Robberecht W, Callewaert $\mathrm{G}$ (2009). Differential contribution of the $\mathrm{Na}(+)-\mathrm{K}(+)-2 \mathrm{Cl}(-)$ cotransporter NKCC1 to chloride handling in rat embryonic dorsal root ganglion neurons and motor neurons. FASEB J. 23:1168-1176.

De Groat WC. (1970). The actions of gamma-aminobutyric acid and related amino acids on mammalian autonomic ganglia. J Pharmacol Exp Ther. 172:384-396. PMID:4315

De Groat WC. (1972). GABA-depolarization of a sensory ganglion: antagonism by picrotoxin and bicuculline. Brain Res. 1972;38(2):429-432.

Deschenes M, Feltz P, Lamour Y. (1976). A model for an estimate in vivo of the ionic basis of presynaptic inhibition: an intracellular analysis of the GABA-induced depolarization in rat dorsal root ganglia. Brain Res. 118:486-493

Dobó, E., Kása,P., Wenthold,R.J., Joó,F.,and Wolff,J.R. (1989). Evidence for GABAergic fibers entering the superior cervical ganglion of rat from the preganglionic nerve trunk. Histochemistry 92, 133-136.

Du X, Hao H, Yang Y, Huang S, Wang C, Gigout S, Ramli R, Li X, Jaworska E, Edwards I, Deuchars J, Yanagawa Y, Qi J, Guan B, Jaffe DB, Zhang H, Gamper N. (2017). Local GABAergic signaling within sensory ganglia controls peripheral nociceptive transmission. J Clin Invest. 127:1741-1756. PMID: 28375159 
Elinos D, Rodríguez R, Martínez LA, Zetina ME, Cifuentes F, Morales MA. (2016) Segregation of Acetylcholine and GABA in the rat superior cervical ganglia: functional correlation. Front Cell Neurosci. 10:91. doi: 10.3389/fncel.2016.00091. PMID: 27092054

Eugène D.(1987). Fast non-cholinergic depolarizing postsynaptic potentials in neurons of rat superior cervical ganglia. Neurosci Lett. 78:51-56. PMID:3039421

Fattorini G, Melone M, Sánchez-Gómez MV, Arellano RO, Bassi S, Matute C, Conti F. (2017). GAT-1 mediated GABA uptake in rat oligodendrocytes. Glia. 65:514-522.

Gallagher JP, Higashi H, Nishi S. (1978). Characterization and ionic basis of GABA-induced depolarizations recorded in vitro from cat primary afferent neurones. J Physiol. 275:263-282.

Ganguly K, Schinder AF, Wong ST, Poo M. (2001). GABA itself promotes the developmental switch of neuronal GABAergic responses from excitation to inhibition. Cell. 105:521-532.

Gaspary HL, Wang W \& Richerson GB (1998). Carrier-mediated GABA release activates GABA receptors on hippocampal neurons. J Neurophysiol 80, 270-281.

Guastella J, Nelson N, Nelson H, Czyzyk L, Keynan S, Miedel MC, Davidson N, Lester HA, Kanner BI (1990). Cloning and expression of a rat brain GABA transporter. Science. 249:1303-1306.

PMID:1975955

Hökfelt T, Ljungdahl A. (1970). Cellular localization of labeled gamma-aminobutyric acid (3H-GABA) in rat cerebellar cortex: an autoradiographic study. Brain Res. 22(3):391-396. PMID:5505543

Ito, T., Hioki,H., Nakamura,K., Tanaka,Y., Nakade,H., Kaneko,T.,et al. (2007). Gamma-aminobutyric acid-containing sympathetic preganglionic neurons in rat thoracic spinal cord send their axons to the superior cervical ganglion. J. Comp. Neurol. 502, 113-125

Iversen, L.L. and Johnston G.A,R.. GABA uptake in rat central nervous system: comparison of uptake in slices and homogenates and the effects of some inhibitors. J. Neurochem. $18,1971,1939-1950$.

Iversen LL, Kelly JS. (1975). Uptake and metabolism of gamma-aminobutyric acid by neurones and glial cells. Biochem Pharmacol. 24:933-938. PMID:1156449

Iversen, LL, Neal MJ. (1968). The uptake of 3H-GABA by slices of rat cerebral cortex. J. Neurochem. 15: 1141-1149.

Kanaka C, Ohno K, Okabe A, Kuriyama K, Itoh T, Fukuda A, Sato K. (2001) The differential expression patterns of messenger RNAs encoding $\mathrm{K}-\mathrm{Cl}$ cotransporters $(\mathrm{KCC} 1,2)$ and $\mathrm{Na}-\mathrm{K}-2 \mathrm{Cl}$ cotransporter (NKCC1) in the rat nervous system. Neuroscience. 104:933-946

Kinney, GA (2005). GAT-3 transporters regulate inhibition in the neocortex. J.Neurophysiol 94:45334537. 
Lee S, Yoon BE, Berglund K, Oh SJ, Park H, Shin HS, Augustine GJ, Lee CJ (2010). Channel-mediated tonic GABA release from glia. Science. 330:790-796. PMID: 20929730

Mager S, Naeve J, Quick M, Labarca C., Davidson N Lester HA. (1993) Steady states, charge movements, and rates for a cloned GABA transporter expressed in Xenopus oocytes. Neuron 10: 177-188

McBride WJ, Klingman JD (1972) The effects of electrical stimulation and ionic alterations on the metabolism of amino acids and proteins in excised superior cervical ganglia of the rat. .

J Neurochem. 19:865-880. PMID:5030988

Melone M, Ciappelloni S, Conti F. (2015). A quantitative analysis of cellular and synaptic localization of GAT-1 and GAT-3 in rat neocortex. Brain Struct Funct. 220:885-897.

Nagata Y, Yokoi Y, Tsukada Y. (1966). Studies on free amino acid metabolism in excised cervical sympathetic ganglia from the rat. J Neurochem. 13:1421-1431. PMID:5962022

Naik AK, Pathirathna S, Jevtovic-Todorovic V. (2008). GABAA receptor modulation in dorsal root ganglia in vivo affects chronic pain after nerve injury. Neuroscience. 154:1539-1553.

Nishi, S., Minota, S. \& Kaczmar, A. G. (1974). Primary afferent neurones: the ionic mechanism of GABA-mediated depolarization. Neuropharmacology 13:215-219.

Obata K, Yamanaka H, Fukuoka T, Yi D, Tokunaga A, Hashimoto N,Yoshikawa H, Noguchi K (2003) Contribution of injured and uninjured dorsal root ganglion neurons to pain behavior and the changes in gene expression following chronic constriction injury of the sciatic nerve in rats. Pain 101:65-77.

Park, JP, Joon, JJ, Zheng, H3, Patel, KP, Stern, JE (2009). Regulation of tonic GABA inhibitory function, presympathetic neuronal activity and sympathetic outflow from the paraventricular nucleus by astroglial GABA transporters. J Physiol 587: 4645-4660

Payne JA, Rivera C, Voipio J, Kaila K. (2003) Cation-chloride cotransporters in neuronal communication, development and trauma. Trends Neurosci 26: 199-206.

Rossi DJ, Hamann M, Attwell D. (2003). Multiple modes of GABAergic inhibition of rat cerebellar granule cells. J Physiol. 548:97-110. PMID: 12588900

Schon F, Kelly JS (1974) The characterization of ${ }^{3} \mathrm{H}-\mathrm{GABA}$ uptake into the satellite glial cells of rat sensory ganglia. Brain Res 66: 289-300.

Semyanov A, Walker MC, Kullmann DM.(2003). GABA uptake regulates cortical excitability via cell type-specific tonic inhibition. Nat Neurosci. 6:484-290. PMID:12679782

Stumpf, W. E. \& Roth, L. J. (1966). High resolution autoradiography with dry-mounted, freeze-dried sections. J. Histochem. Cytochem. 14, 274-287.

Unichenko,P., Kirischuk,S., Luhmann,H.J. (2015). GABA transporters control gabaergic neurotransmission in the mouse subplate. Neuroscience 304: 217-227 
Wall MJ \& Usowicz MM (1997). Development of action potential dependent and independent spontaneous GABAA receptor mediated currents in granule cells of postnatal rat cerebellum. Eur J Neurosci 9, 533-548.

Walsh JM, Bowery NG, Brown DA, Clark JB. (1974). Metabolism of gamma-aminobutyric acid (GABA) by peripheral nervous tissue. J Neurochem. 22:1145-1147.

Wolff, J.R., Joó,F., Kása,P., Storm-Mathiesen,J., Toldi,J., Balcar,V.J. (1986). Presence of neurons with GABA-like immunoreactivity in the superior cervical ganglion of the rat. Neurosci. Lett. 71, 157-162.

Wolff, J.R., Kása,P., Dobo,E., Wenthold,R.J., Joo,F. (1989).Quantitative analysis of the number and distribution of neurons richly innervated by GABA- immunoreactive axons in the rat superior cervical ganglion. J. Comp.Neurol. 282, 264-273.

Young JA, Brown DA, Kelly JS, Schon F. (1973) Autoradiographic localization of sites of (3H)gammaaminobutyric acid accumulation in peripheral autonomic ganglia. Brain Res. 63:479-486.

5396 words including title, abstract, highlights, key words, references and figure legends 


\section{Figure legends.}

Figure 1. Autoradiographs of extraneuronal ${ }^{3} \mathrm{H}-\mathrm{GABA}$ uptake into isolated rat superior cervical ganglia. Ganglia were incubated in (a) $1 \mu \mathrm{M}^{3} \mathrm{H}-\mathrm{GABA}$ or (b) $1 \mu \mathrm{M}{ }^{3} \mathrm{H}-\mathrm{GABA}$ plus $1 \mathrm{mM}$ unlabelled GABA (both in the presence of $10 \mu \mathrm{M}$ amino-oxyacetic acid). Ganglia were then rinsed for $60 \mathrm{~min}$ in non-radioactive solution, fixed, embedded, sectioned at $5 \mu \mathrm{m}$ and the sections exposed to photographic emulsion for 28 days. The autoradiographs are viewed under darkfield optics: the silver grains appear white; the black "holes" are neuron somata. (Adapted from Bowery et al., 1976a; q.v for experimental details).

Figure 2. Indirect GABAmimetic actions of substrates for the neuroglial GABAtransporter on adjacent sympathetic neurons. Records show depolarizations of an isolated rat superior cervical ganglion by GABA and analogues (a) before ("control") and (b) after incubating the ganglion in $1 \mathrm{mM}$ GABA for $60 \mathrm{~min}$ ("post-load") followed by 60 min wash. The GABA was taken up into the neuroglial cells as shown in Fig.1(b) and was calculated from dansylation measurements to increase neuroglial [GABA] concentration by 3.6 times, from 1.6 to $5.8 \mathrm{mM}$ (see Bowery et al., 1976). This procedure did not affect the response to exogenous GABA, but strikingly increased the responses to BABA ( $\beta$ aminobutyric acid) and BALA ( $\beta$-alanine), two substrates for the neuroglial GABA carrier. The two responses to 1 and $6 \mu \mathrm{M}$ GABA on the right are calibrating responses taken at the end of the experiment. From these it was calculated that the extra GABA released from the GABA-loaded glial cells generated 2.2 $\mu \mathrm{M}$ interstitial GABA in the case of BALA and $1.3 \mu \mathrm{M}$ in the case of BALA. (From Bowery et al., 1976, q.v. for details). Numbers adjacent to individual responses indicate the order of drug applications.

Figure 3. $p$-aminobutyrylcholine (GABACh) acts like GABA, not like acetylcholine. Records show surface depolarizations of two isolated rat superior cervical ganglia produced by 4 min applications of $100 \mu \mathrm{M}$ GABA (G), $5 \mu \mathrm{M}$ carbachol (C) or $200 \mu \mathrm{M} \gamma$-aminobutyrylcholine (GCh) at => $15 \mathrm{~min}$ intervals. Records in A show that the action of GABACh was not affected by $2.6 \mu \mathrm{M}$ hyoscine (hyo) or a combination of $2.6 \mu \mathrm{M}$ hyoscine plus $0.83 \mathrm{mM}$ hexamethonium (hyo + hex), which inhibited the action of carbachol. Records in B show that the effect of GABACh was reduced by 10 and $100 \mu \mathrm{M}$ bicuculline (bic) pari passu the reduced response to GABA (G). From Bowery \& Brown, 1972). 
Fig 1

a $1 \mu \mathrm{M}\left[{ }^{3} \mathrm{H}\right]-\mathrm{GABA}$

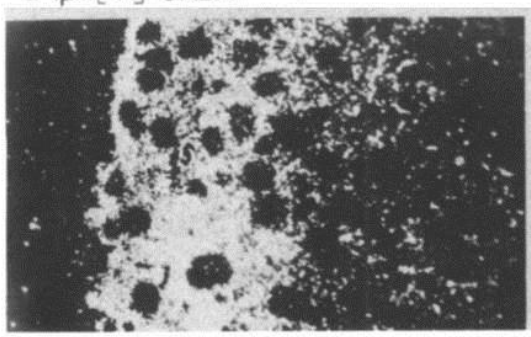

b $1 \mathrm{~mm}\left[{ }^{3} \mathrm{H}\right]-\mathrm{GABA}$

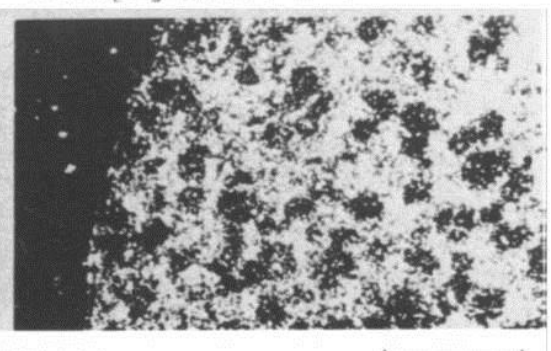

$100 \mu \mathrm{m}$

Figure 1. Autoradiographs of extraneuronal ${ }^{3} \mathrm{H}-\mathrm{GABA}$ uptake into isolated rat superior cervical ganglia. Ganglia were incubated in (a) $1 \mu \mathrm{M}^{3} \mathrm{H}-\mathrm{GABA}$ or (b) $1 \mu \mathrm{M}^{3} \mathrm{H}$-GABA plus $1 \mathrm{mM}$ unlabelled GABA (both in the presence of $10 \mu \mathrm{M}$ amino-oxyacetic acid). Ganglia were then rinsed for $60 \mathrm{~min}$ in non-radioactive solution, fixed, embedded, sectioned at $5 \mu \mathrm{m}$ and the sections exposed to photographic emulsion for 28 days. The autoradiographs are viewed under darkfield optics: the silver grains appear white; the black "holes" are neuron somata. (Adapted from Bowery et al., 1976a; q.v for experimental details). 


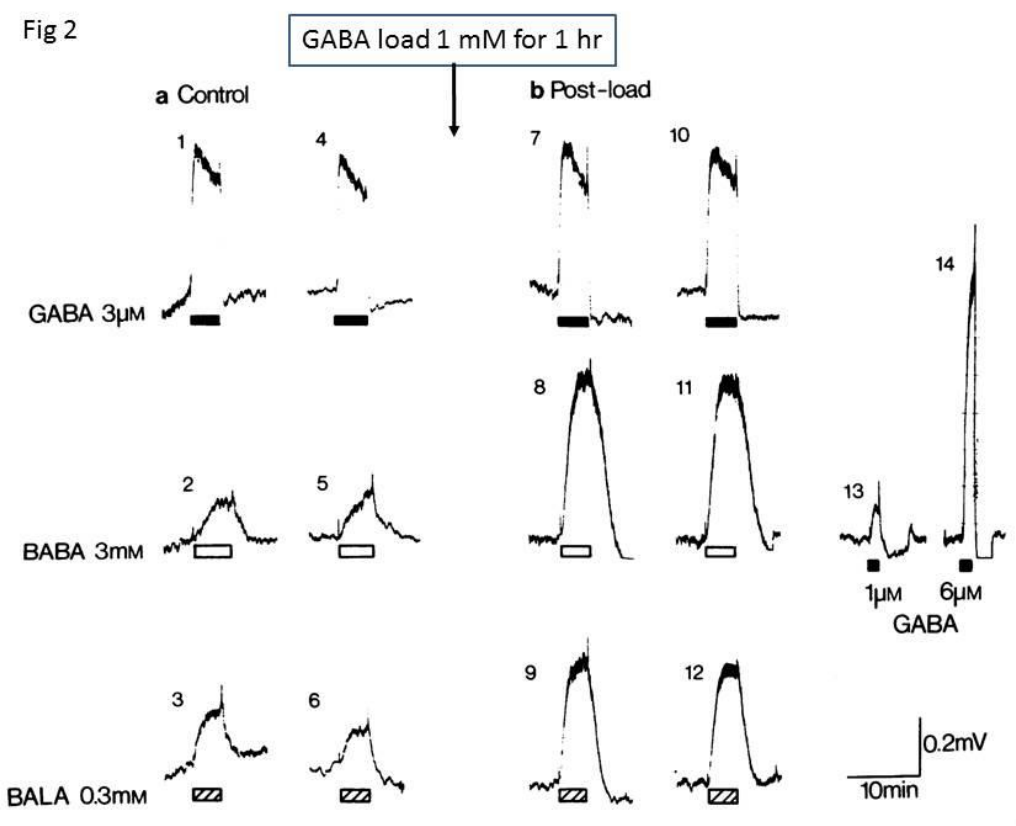

Figure 2. Indirect GABAmimetic actions of substrates for the neuroglial GABAtransporter on adjacent sympathetic neurons. Records show depolarizations of an isolated rat superior cervical ganglion by GABA and analogues (a) before ("control") and (b) after incubating the ganglion in $1 \mathrm{mM} \mathrm{GABA}$ for $60 \mathrm{~min}$ ("post-load") followed by $60 \mathrm{~min}$ was. The GABA was taken up into the neuroglial cells as shown in Fig.1(b) and was calculated from dansylation measurements to increase neuroglial [GABA] concentration by 3.6 times, from 1.6 to $5.8 \mathrm{mM}$ (see Bowery et al., 1976). This procedure did not affect the response to exogenous GABA, but strikingly increased the responses to BABA ( $\beta$ aminobutyric acid) and BALA ( $\beta$-alanine), two substrates for the neuroglial GABA carrier. The two responses to 1 and $6 \mu \mathrm{M}$ GABA on the right are calibrating responses taken at the end of the experiment. From these it was calculated that the extra GABA released from the GABA-loaded glial cells generated 2.2 $\mu \mathrm{M}$ interstitial GABA in the case of BALA and 1.3 $\mu \mathrm{M}$ in the case of BALA. (From Bowery et al., 1976, q.v. for details). Numbers adjacent to individual responses indicate the order of drug applications. 
A
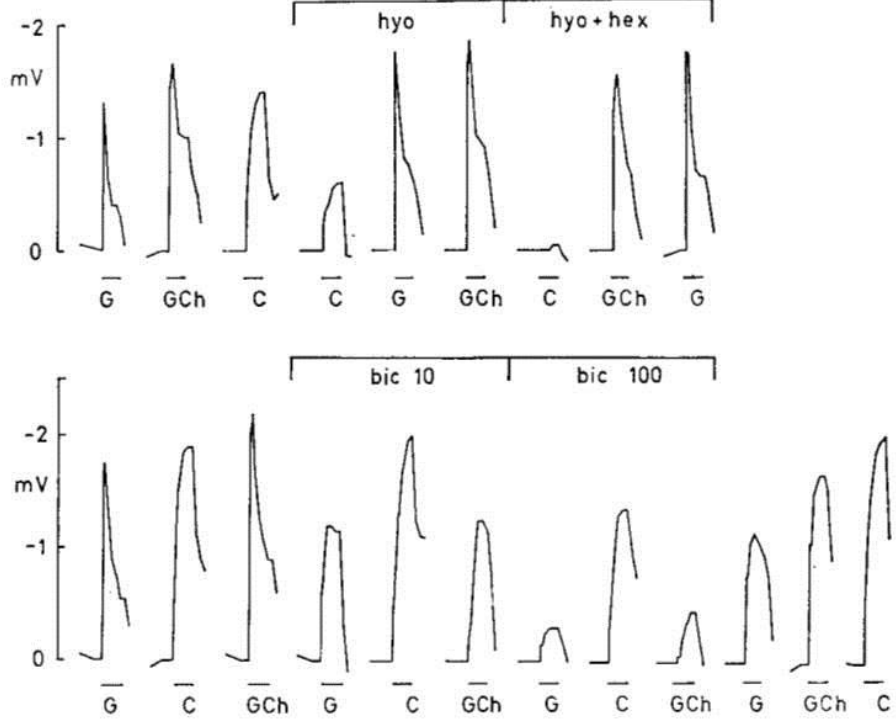

Figure 3. $v$-aminobutyrylcholine (GABACh) acts like GABA, not like acetylcholine. Records show surface depolarizations of two isolated rat superior cervical ganglia produced by 4 min applications of $100 \mu \mathrm{M} \mathrm{GABA}(\mathrm{G}), 5 \mu \mathrm{M}$ carbachol (C) or $200 \mu \mathrm{M} \gamma$-aminobutyrylcholine (GCh) at $>=15 \mathrm{~min}$ intervals. Records in A show that the action of GABACh was not affected by $2.6 \mu \mathrm{M}$ hyoscine (hyo) or a combination of $2.6 \mu \mathrm{M}$ hyoscine plus $0.83 \mathrm{mM}$ hexamethonium (hyo + hex), which inhibited the effect of carbachol. Records in B show that the effect of GABACh was reduced by 10 and $100 \mu \mathrm{M}$ bicuculline (bic) pari passu the reduced response to GABA (G). From Bowery \& Brown, 1972). 